\title{
Analisis Kepuasan Pengguna Website Asuransi Untuk Peningkatan Pelayanan Asuransi Studi Kasus www.Cakrawalaproteksi.Com
}

\author{
Syafitri Mona Sari, Firdaus \& A. Haidar Mirza \\ Universitas Bina Darma \\ Email:monadjauhari@gmail.com
}

\begin{abstract}
Currently, technology has developed quite rapidly and covers all aspects, including in the insurance industry. Almost every insurance company has a website or social media that can be accessed by all internet users as a means of promotion and transactions. PT. Asuransi Cakrawala Proteksi is an insurance company that also carries out promotions through websites and social media. This research will discuss the customer satisfaction of PT. Asuransi Cakrawala Protection with the role of social media. Customer satisfaction is determined by looking at the difference between the actual value received and the expected value using the website and social media Facebook. From calculating the level of customer satisfaction with ServQual dimensions and simple analysis, a strategy will be produced to maintain or increase customer satisfaction.
\end{abstract}

Keywords: insurance, social media, website, servqual dimension

\section{Pendahuluan}

Industri asuransi di Indonesia pada saat ini mengalami pertumbuhan yang cukup signifikan. Asosiasi Asuransi Umum Indonesia (AAUI) telah memperkirakan pertumbuhan premi industri asuransi umum di Tanah Air akan naik sekitar 15 persen sampai dengan 20 persen. Berdasarkan data AAUI, struktur pasar industri asuransi sampai dengan September 2015 tercatat ada 78 perusahaan asuransi umum atau berkurang satu perusahaan dibandingkan di 2014 dimana terdapat 79 perusahaan asuransi umum. Sementara itu, sampai dengan September Tahun 2015 perusahaan reasuransi tercatat semula sebanyak enam perusahaan atau bertambah sebanyak satu perusahaan bila dibandingkan di 2014 yang sebanyak lima perusahaan. Sedangkan insurance broker sampai September 2015 tercatat cukup banyak yaitu sebanyak 163 perusahaan. Perusahaan - perusahan asuransi tersebut harus menggunakan segala upaya untuk memperluas pasar dalam menghadapi pesaing. Untuk bertahan serta unggul dalam persaingan, perusahaan asuransi harus melakukan pelayanan yang berkualitas, cepat dan secara kontinyu kepada pelanggan. Kemajuan teknologi saat ini telah mengantarkan manusia untuk menciptakan bentuk baru dalam berinteraksi dan bersosialisasi. Pesatnya kemajuan teknologi tidak bisa dipungkiri semakin memanjakan manusia, contohnya dalam hal berkomunikasi. Interaksi yang terjadi dengan adanya bantuan teknologi menjadi semakin mudah dan sangat membantu. Keberadaan media jejaring sosial dapat menimbulkan dampak positif dan juga dampak negative pada masyarakat. Kecanggihan sosial teknologi dan sosial media dalam bentuk bisnis dapat berupa alat pemasaran bagi perusahaan, dimana ukuran dan jenis perusahaan tidak perlu di perhatikan, melainkan perusahaan perlu berhati- hati bagaimana sosial tehnologi tersebut media sosial sebagai alat pemasaran tersebut digunakan secara benar dan efektif (Antoni, Akbar \& Fatoni, 2018; Akbar \& Antoni, 2019; Ariana, Azim \& Antoni, 2020).

\section{Tinjauan Literatur}

Definisi umum tentang service quality atau yang seringkali disingkat SERVQUAL dinyatakan 
oleh Parasuraman, dkk (1990) menggunakan skala 1-7 (untuk dapat memberikan respons terhadap suatu pernyataan atas satu aspek kualitas jasa), yakni sangat tidak setuju (1) sampai sangat setuju (7). Menurut penelitian yang dilakukan oleh Parasuraman dan kawan-kawan disimpulkan dari ke-5 dimensi tersebut terdapat kepentingan relatif yang berbedabeda.Menurut Parasuraman (1990), ada 5 dimensi SERVQUAL sebagai berikut:

1. Tangibles, atau bukti fisik yaitu kemampuan suatu perusahaan dalam menunjukkan eksistensinya pada pihak eksternal. Penampilan dan kemampuan sarana dan prasarana fisik perusahaan dan keadaan lingkungan sekitarnya adalah bukti nyata dari pelayanan yang diberikan oleh pemberi jasa. ini meliputi fasilitas fisik (Gedung, Gudang, dan lainnya), teknologi (peralatan dan perlengkapan yang dipergunakan), serta penampilan pegawainya. Secara singkat dapat diartikan sebagai penampilan fasilitas fisik, peralatan, personil, dan materi komunikasi.

2. Reliability, atau keandalan yaitu kemampuan perusahaan untuk memberikan pelayanan sesuai yang dijanjikan secara akurat dan terpercaya. Harus sesuai dengan harapan pelanggan berarti kinerja yang tepat waktu, pelayanan tanpa kesalahan, sikap simpatik dan dengan akurasi tinggi. Secara singkat dapat diartikan sebagai kemampuan untuk memberikan layanan yang dijanjikan secara akurat, tepat waktu, dan dapat dipercaya.

3. Responsiveness, atau ketanggapan yaitu suatu kemauan untuk membantu dan memberikan pelayanan yang cepat (responsive) dan tepat kepada pelanggan, dengan penyampaian informasi yang jelas. Membiarkan konsumen menunggu tanpa alasan yang jelas menyebabkan persepsi yang negatif dalam kualitas pelayanan. Secara singkat dapat diartikan sebagai kemauan untuk membantu pelanggan dengan memberikan layanan yang baik dan cepat.

4. Assurance, atau jaminan serta kepastian yaitu pengetahuan, kesopan santunan, dan kemampuan para pegawai perusahaan agar dapat menumbuhkan rasa percaya pelanggan kepada perusahaan. Terdiri dari komponen: komunikasi (Communication), kredibilitas (Credibility), keamanan (Security), kompetensi (Competence), dan sopan santun (Courtesy). Secara singkat dapat diartikan sebagai pengetahuan serta keramahtamahan personil dan kemampuan personil untuk dapat dipercaya dan diyakini

5. Empathy, yaitu memberikan perhatian yang tulus dan bersifat individual atau pribadi yang diberikan kepada pelanggan yaitu dengan berupaya memahami keinginan konsumen dimana suatu perusahaan diharapkan memiliki suatu pengertian dan pengetahuan tentang pelanggan, untuk memahami kebutuhan pelanggan secara spesifik, serta memiliki waktu pengoperasian yang nyaman bagi pelanggan. Secara singkat dapat diartikan sebagai usaha untuk mengetahui dan mengerti kebutuhan pelanggan secara individual.

Menurut Parasuraman, dkk (1990), Reliability secara konsisten adalah merupakan dimensi yang paling kritis, kemudian di tingkat ke-2 assurance, disusul oleh ke-3 oleh tangibles (terutama oleh perusahaan perbankan), ke-4 oleh responsiveness, dan kadar kepentingan terendah adalah empathy.

\section{Metode Penelitian}

Metode Penelitian yang digunakan adalah metode survey yaitu metode yang digunakan untuk mengumpulkan data atau informasi tentang populasi yang besar dengan menggunakan sampel yang relatif kecil (Fauzi, Dencik \& Asiati, 2019). Populasi tersebut bisa saja berkenaan dengan orang, instansi, lembaga, organisasi dan unit-unit kemasyarakatan dan lain-lain, tetapi sumber 
utamanya adalah orang. Desain survey tergantung pada penggunaan jenis kuisoner. Survey akan memerlukan populasi yang besar jika peneliti menginginkan hasilnya mencerminkan kondisi nyata, semakin besar sample survey semakin memberikan hasil akurat. Dalam penelitian survei terdapat tiga tujuan utama yaitu menggambarkan keadaan saat itu, mengidentifikasi secara terukur keadaan sekarang untuk membandingkan, menentukan hubungan kejadian yang spesifik.

Secara umum langkah-langkah yang dilakukan pada penelitian ini adalah sebagai berikut :

1. Identifikasi dan analisis masalah seputar Asuransi, media sosial, dan keterkaitan media sosial dalam membantu peningkatan pelayan asuransi. Pada tahap ini juga penulis akan mencari dan mempelajari Literatur - literature terkait lebih dalam lagi.

2. Menganalisis faktor dan kriteria. Penulis akan mengambil data secara langsung dengan menggunakan metode survey. Kuisioner disiapkan dengan menggunakan analisis Model SERVQUAL yang memiliki 5 dimensi/variabel berdasarkan tingkat kepentingan relatifnya yaitu responsiveness $(R)$, tangibles $(T)$, emphaty $(E)$, assurance $(A)$, dan reliability $(R e)$. Setelah kuisioner disiapkan maka selanjutnya akan ditentukan koresponden - koresponden untuk memulai penyebaran kuisioner-kuisioner tersebut.

3. Melakukan Uji reliabilitas dan validitas data harapan dan kenyataan yang diterima konsumen akan menggunakan IBM SPSS 20. Selanjutnya akan digunakan analisis GAP yang sesuai dengan hasil yang diperoleh.

4. Menganalisis Hasil yang merupakan tahapan akhir dari rangkaian proses sebelumnya. Pada tahap ini

penulis bisa menilai seberapa besar manfaat website dan media Sosial Facebook untuk meningkatkan pelayanan asuransi serta hal-hal apa saja yang perlu ditingkatkan.

\section{Hasil dan Pembahasan}

Setelah dilakukan penyebaran kuesioner yang berisi pernyataan tertulis kepada 100 nasabah PT. Asuransi Cakrawala Proteksi dengan jumlah 18 pernyataan (terdiri atas pernyataan tentang harapan dan pernyataan tentang persepsi pelanggan terhadap pelayanan aplikasi Website yang diberikan oleh PT. Asuransi Cakrawala Proteksi Cabang). Data kuesioner tersebut kemudian diolah menggunakan penghitungan komputasi program SPSS (Statistical Product and Service Solution) versi 22. Pengolahan data dilakukan mulai dari uji validitas dan reliabilitas tiap butir pernyataan variable Tangible, Emphaty, Responsiveness, Reliability, dan Assurance, karakteristik ke 100 responden, dan frekuensi tiap variable yang ada hingga didapatlah tingkat kepuasan nasabah pengguna website tersebut.

\subsection{Hasil Penelitian}

Pengolahan hasil penelitian mencakup penyusunan tabel pengujian persyaratan analisis, karakteristik responden (nasabah), pengukuran tiap butir pernyataan tingkat kepuasan nasabah pengguna website PT. Asuransi Cakrawala Proteksi. Hasil pengolahan data adalah sebagai berikut :

\section{Uji Validitas dan Uji Reliabilitas}

Sebelum uji statistik dilakukan, item pernyataan akan terlebih dahulu diuji dengan menggunakan uji validitas dan reliabilitas. Data yang diuji berasal dari lima dimensi penilaian terhadap kualitas jasa yakni Tangible, Emphaty, Responsiveness, Reliability, dan Assurance. Dari 18 butir pernyataan yang diberikan setelah dilakukan uji validitas dan reabilitas ternyata 
hanya 16 butir pernyataan yang valid. Berikut dibawah ini hasil validitas dan reabilitas instrumen / kuesioner.

Setelah dilakukan analisa terhadap tingkat kepuasan pengguna secara keseluruhan diketahui bahwa nasabah cukup puas terhadap pelayanan PT. Asuransi Cakrawala Proteksi baik secara langsung ataupun melalui website. Akan tetapi berdasarkan hasil rata-rata tingkat kepuasan pelanggan tiap variabelnya bahwa variabel responsiveness (ketanggapan) memiliki tingkat kepuasan paling tinggi kemudian di variabel reliability (kehandalan) variabel tangibles (bukti fisik), variable assurance (jaminan) dan lalu terakhir divariabel emphaty (empati).

\begin{tabular}{|c|c|c|c|c|c|c|c|}
\hline \multicolumn{8}{|c|}{ Tabulasi Hasil Kuisioner } \\
\hline \multirow{2}{*}{ No. } & \multirow{2}{*}{ Dimensi Servqual } & \multirow{2}{*}{ Pertanyaan } & \multicolumn{5}{|c|}{ Penilaian } \\
\hline & & & 1 & 2 & 3 & 4 & 5 \\
\hline 1 & \multirow{5}{*}{ Reliability } & Website mudah dibuka & & & 2 & 45 & 53 \\
\hline 2 & & Waktu load untuk membuka wesite ini cepat & & & & 59 & 41 \\
\hline 3 & & Terdapat informasi detil tentang produk produk asuransi & & & 5 & 58 & 37 \\
\hline 4 & & Tersedia gambar dari produk produk asuransi tersebut pada website & & & & 59 & 41 \\
\hline 5 & & Syarat dan ketentuan untuk pembelian produk produk asuransi mudah ditemukan pada website & & & 4 & 58 & 38 \\
\hline 6 & \multirow{3}{*}{ Tangibles } & Website terorganisasi dengan baik & & 1 & & 63 & 36 \\
\hline 7 & & Navigasi terstandaris asi secara konsisten & & & 16 & 56 & 28 \\
\hline 8 & & Website mudah dimengerti & & 1 & & 63 & 36 \\
\hline 9 & \multirow{4}{*}{ Emphaty } & Tampilan website menarik dan berisi informasi yang lengkap & & & 3 & 65 & 32 \\
\hline 10 & & Website ini menyediakan informasi yang akurat bagi konsumen & & & 9 & 61 & 30 \\
\hline 11 & & Informasi yang tersedia di website jelas bagi nasabah & & 6 & 13 & 55 & 26 \\
\hline 12 & & Komunikasi dengan pihak perusahaan melalui website & 1 & 21 & 18 & 34 & 26 \\
\hline 13 & \multirow{3}{*}{ Responsiveness } & Masukkan dari konsumen dilihat untuk mengukur kepuasan konsumen & & & & 26 & 74 \\
\hline 14 & & Permintaan direspon dalam waktu 24 jam & & & & 32 & 68 \\
\hline 15 & & Pertanyaan dan komplain diselesaikan dalam waktu 24 jam & & & & 55 & 45 \\
\hline 16 & \multirow{3}{*}{ Assurance } & Tersedia Customer Service yang siap melayani & & 6 & 42 & 51 & 1 \\
\hline 17 & & Terdapat jaminan keamanan informasi pada website & & 1 & & 63 & 36 \\
\hline 18 & & Tersedia penggunaan teknologi baru yang menjamin keamanan berkomunikasi melalui website & & & 16 & 56 & 28 \\
\hline
\end{tabular}

Tabel 1. Hasil Uji Validitas Variabel Reliability (R)

\begin{tabular}{|l|l|c|c|c|}
\hline No & \multicolumn{1}{|c|}{ Pernyataan } & $\begin{array}{c}\text { Corrected } \\
\text { Item-Total } \\
\text { Correlation } \\
\left(\mathrm{r}_{\text {hitung }}\right)\end{array}$ & $\begin{array}{c}\mathrm{r}_{\text {tabel }} \\
\mathbf{N}=\mathbf{1 0 0}\end{array}$ & Ket \\
\hline 1 & Website mudah dibuka & 0.343 & 0.195 & Valid \\
\hline 2 & Waktu load untuk membuka wesite ini cepat & 0.677 & 0.195 & Valid \\
\hline 3 & Terdapat informasi detil tentang produk produk asuransi & 0.577 & 0.195 & Valid \\
\hline 4 & $\begin{array}{l}\text { Tersedia gambar dari produk produk asuransi tersebut } \\
\text { pada website }\end{array}$ & 0.677 & 0.195 & Valid \\
\hline 5 & $\begin{array}{l}\text { Syarat dan ketentuan untuk pembelian produk produk } \\
\text { asuransi mudah ditemukan pada website }\end{array}$ & 0.468 & 0.195 & Valid \\
\hline
\end{tabular}


Dari hasil uji coba instrumen dilakukan pada 100 responden menunjukkan hasil uji validitas dari 5 (lima) item pernyataan variabel reliabilty $(\mathrm{R})$ tersebut valid dianggap memenuhi syarat dengan nilai $\mathrm{r}_{\text {hitung }}>\mathrm{r}_{\text {tabel }}(0,195)$. Hal ini berarti semua item pernyataan yang ada pada instrumen tersebut dapat dijadikan sebagai indikator sebagai alat ukur yang valid dalam analisis selanjutnya.

Tabel 2 Hasil Uji Reliabilitas Variabel Reliability (R)

\begin{tabular}{|c|c|}
\hline Cronbach's Alpha & N of Items \\
\hline 0.769 & 5 \\
& \\
\hline
\end{tabular}

Dari hasil uji reliabilitas variabel reliability (R) diatas yang terdiri dari 5 (lima) item pernyataan, nilai Cronbach's Alpha sebesar 0,769 (diatas 0,60) sehingga dapat disimpulkan bahwa kuesioner tersebut reliabel.

Tabel 3. Hasil Uji Validitas Variabel Tangibles (T)

\begin{tabular}{|c|l|c|c|l|}
\hline No & \multicolumn{1}{|c|}{ Pernyataan } & $\begin{array}{c}\text { Corrected } \\
\text { Item-Total } \\
\text { Correlation } \\
\left(\mathrm{r}_{\text {hitung }}\right)\end{array}$ & $\begin{array}{c}\mathrm{r}_{\text {tabel }} \\
\mathbf{N}=\mathbf{1 0 0}\end{array}$ & Ket \\
\hline 1 & Website terorganisasi dengan baik & 0.755 & 0.195 & Valid \\
\hline 2 & Navigasi terstandarisasi secara konsisten & 0.285 & 0.195 & Valid \\
\hline 3 & Website mudah dimengerti & 0.755 & 0.195 & Valid \\
\hline
\end{tabular}

Dari hasil uji coba instrumen dilakukan pada 100 responden menunjukkan hasil uji validitas dari 3 (tiga) item pernyataan variabel tangibles $(\mathrm{T})$ tersebut valid dianggap memenuhi syarat dengan nilai $r_{\text {hitung }}>r_{\text {tabel }}(0,195)$. Hal ini berarti semua item pernyataan yang ada pada instrumen tersebut dapat dijadikan sebagai indikator sebagai alat ukur yang valid dalam analisis selanjutnya.

Tabel 4. Hasil Uji Reliabilitas Variabel Tangibles (T)

\begin{tabular}{|c|c|}
\hline Cronbach's Alpha & N of Items \\
\hline 0.739 & 3 \\
& \\
\hline
\end{tabular}

Dari hasil uji reliabilitas variabel tangibles (R) diatas yang terdiri dari 3 (tiga) item pernyataan, nilai Cronbach's Alpha sebesar 0,655 (diatas 0,60) sehingga dapat disimpulkan bahwa kuesioner tersebut reliabel. 
Tabel 5 Hasil Uji Validitas Variabel Emphaty (E)

\begin{tabular}{|c|c|c|c|c|}
\hline No & Pernyataan & $\begin{array}{c}\text { Corrected } \\
\text { Item-Total } \\
\text { Correlation } \\
\left(\mathrm{r}_{\text {hitung }}\right)\end{array}$ & $\begin{array}{c}\mathrm{r}_{\text {tabel }} \\
\mathbf{N}=\mathbf{1 0 0}\end{array}$ & Ket \\
\hline 1 & $\begin{array}{l}\text { Tampilan website menarik dan berisi informasi } \\
\text { yang lengkap }\end{array}$ & 0.485 & 0.195 & Valid \\
\hline 2 & $\begin{array}{l}\text { Website ini menyediakan informasi yang akurat } \\
\text { bagi konsumen }\end{array}$ & 0.645 & 0.195 & Valid \\
\hline 3 & $\begin{array}{l}\text { Informasi yang tersedia di website jelas bagi } \\
\text { nasabah }\end{array}$ & 0.494 & 0.195 & Valid \\
\hline 4 & $\begin{array}{l}\text { Komunikasi dengan pihak perusahaan melalui } \\
\text { website }\end{array}$ & 0.552 & 0.195 & Valid \\
\hline
\end{tabular}

Dari hasil uji coba instrumen dilakukan pada 100 responden menunjukkan hasil uji validitas dari 4 (empat) item pernyataan variabel emphaty (E) tersebut valid dianggap memenuhi syarat dengan nilai $\mathrm{r}_{\text {hitung }}>\mathrm{r}_{\text {tabel }}(0,195)$. Hal ini berarti semua item pernyataan yang ada pada instrumen tersebut dapat dijadikan sebagai indikator sebagai alat ukur yang valid dalam analisis selanjutnya.

Tabel 6. Hasil Uji Reliabilitas Variabel Emphaty (E)

\begin{tabular}{|c|c|}
\hline Cronbach's Alpha & N of Items \\
\hline 0.713 & 4 \\
& \\
\hline
\end{tabular}

Dari hasil uji reliabilitas variabel emphaty (E) diatas yang terdiri dari 4 (empat) item pernyataan, nilai Cronbach's Alpha sebesar 0,713 (diatas 0,60) sehingga dapat disimpulkan bahwa kuesioner tersebut reliabel.

Tabel 7. Hasil Uji Validitas Variabel Responsiveness (Rs)

\begin{tabular}{|c|l|c|c|c|}
\hline No & \multicolumn{1}{|c|}{ Pernyataan } & $\begin{array}{c}\text { Corrected } \\
\text { Item-Total } \\
\text { Correlation } \\
\left(\mathrm{r}_{\text {hitung }}\right.\end{array}$ & $\begin{array}{c}\mathrm{r}_{\text {tabel }} \\
\mathbf{N}=\mathbf{1 0 0}\end{array}$ & Ket \\
\hline 1 & $\begin{array}{l}\text { Masukkan dari konsumen dilihat untuk mengukur } \\
\text { kepuasan konsumen }\end{array}$ & 0.441 & 0.195 & Valid \\
\hline 2 & Permintaan direspon dalam waktu 24 jam & 0.560 & 0.195 & Valid \\
\hline 3 & $\begin{array}{l}\text { Pertanyaan dan komplain diselesaikan dalam waktu 24 } \\
\text { jam }\end{array}$ & 0.033 & 0.195 & $\begin{array}{l}\text { Tidak } \\
\text { Valid }\end{array}$ \\
\hline
\end{tabular}


Dari hasil uji coba instrumen dilakukan pada 100 responden menunjukkan hasil uji validitas dari 3 (dua) item pernyataan variabel responsiveness (Rs) tersebut hanya 2 (dua) item saja yang valid dan dianggap memenuhi syarat dengan nilai $r_{\text {hitung }}>r_{\text {tabel }}(0,195)$. Hal ini berarti hanya 2 (dua) item pernyataan yang ada pada instrumen tersebut yang dapat dijadikan sebagai indikator sebagai alat ukur yang valid dalam analisis selanjutnya.

Tabel 8 Hasil Uji Reliabilitas Variabel Responsiveness (Rs)

\begin{tabular}{|c|c|}
\hline Cronbach's Alpha & N of Items \\
\hline 0.630 & 3 \\
& \\
\hline
\end{tabular}

Dari hasil uji reliabilitas variabel responsiveness (Rs) diatas yang terdiri dari 2 (dua) item pernyataan, nilai Cronbach's Alpha sebesar 0,630 (diatas 0,60) sehingga dapat disimpulkan bahwa kuesioner tersebut reliabel.

Tabel 9. Hasil Uji Validitas Variabel Assurance (A)

\begin{tabular}{|c|l|c|c|c|}
\hline No & \multicolumn{1}{|c|}{ Pernyataan } & $\begin{array}{c}\text { Corrected } \\
\text { Item-Total } \\
\text { Correlation } \\
\left(\mathrm{r}_{\text {hitung }}\right)\end{array}$ & $\begin{array}{c}\mathrm{r}_{\text {tabel }} \\
\mathbf{N}=\mathbf{1 0 0}\end{array}$ & Ket \\
\hline 1 & Tersedia Customer Service yang siap melayani & -0.05 & 0.195 & $\begin{array}{c}\text { Tidak } \\
\text { Valid }\end{array}$ \\
\hline 2 & Terdapat jaminan keamanan informasi pada website & 0.245 & 0.195 & Valid \\
\hline 3 & $\begin{array}{l}\text { Tersedia penggunaan teknologi baru yang menjamin } \\
\text { keamanan berkomunikasi melalui website }\end{array}$ & 0.332 & 0.195 & Valid \\
\hline
\end{tabular}

Dari hasil uji coba instrumen dilakukan pada 100 responden menunjukkan hasil uji validitas dari 3 (dua) item pernyataan variabel Assurance (A) tersebut hanya 2 (dua) item saja yang valid dan dianggap memenuhi syarat dengan nilai $r_{\text {hitung }}>r_{\text {tabel }}(0,195)$. Hal ini berarti hanya 2 (dua) item pernyataan yang ada pada instrumen tersebut yang dapat dijadikan sebagai indikator sebagai alat ukur yang valid dalam analisis selanjutnya.

Tabel 10. Hasil Uji Reliabilitas Variabel Assurance (A)

\begin{tabular}{|c|c|}
\hline Cronbach's Alpha & N of Items \\
\hline 0.622 & 3 \\
& \\
\hline
\end{tabular}

Dari hasil uji reliabilitas variabel Assurance (A) diatas yang terdiri dari 3 (tiga) item pernyataan, nilai Cronbach's Alpha sebesar 0,622 (diatas 0,60) sehingga dapat disimpulkan bahwa kuesioner tersebut reliabel.

Uji validitas dilakukan untuk melihat sejauh mana indikator-indikator yang dapat mewakili 
variabel yang dibentuk dalam penelitian. Variabel dapat dibentuk apabila nilai corrected item total correlation (Skor Korelasi) $>\mathrm{r}(0,195)$. Hasil penelitian menunjukan bahwa variabel tangible, emphaty, responsiveness, reliability, dan assurance dari hasil uji coba instrumen yang dilakukan pada 100 responden di wilayah Palembang, semua item pernyataan yang ada pada instrumen tersebut dapat dijadikan sebagai indikator sebagai alat ukur yang valid dalam analisis selanjutnya.

Dari hasil pengujian berikut nilai rata-rata tingkat kepuasan untuk setiap dimensinya

Tabel 11. Frequency Reliability

\begin{tabular}{|c|c|c|c|c|c|c|}
\hline & & $\begin{array}{l}\text { Website } \\
\text { mudah } \\
\text { dibuka }\end{array}$ & $\begin{array}{l}\text { Waktu load } \\
\text { untuk } \\
\text { membuka } \\
\text { wesite ini } \\
\text { cepat }\end{array}$ & $\begin{array}{c}\text { Terdapat } \\
\text { informasi } \\
\text { detil tentang } \\
\text { produk } \\
\text { produk } \\
\text { asuransi }\end{array}$ & $\begin{array}{c}\text { Tersedia } \\
\text { gambar dari } \\
\text { produk } \\
\text { produk } \\
\text { asuransi } \\
\text { tersebut pada } \\
\text { website }\end{array}$ & $\begin{array}{c}\text { Syarat dan } \\
\text { ketentuan untuk } \\
\text { pembelian produk } \\
\text { produk asuransi } \\
\text { mudah ditemukan } \\
\text { pada website }\end{array}$ \\
\hline \multirow[t]{2}{*}{$\mathrm{N}$} & Valid & 100 & 100 & 100 & 100 & 100 \\
\hline & Missing & 0 & 0 & 0 & 0 & 0 \\
\hline Mean & & 4.5100 & 4.4100 & 4.3200 & 4.4100 & 4.3400 \\
\hline Median & & 5.0000 & 4.0000 & 4.0000 & 4.0000 & 4.0000 \\
\hline Minimum & & 3.00 & 4.00 & 3.00 & 4.00 & 3.00 \\
\hline Maximum & & 5.00 & 5.00 & 5.00 & 5.00 & 5.00 \\
\hline
\end{tabular}

Berdasarkan tabel diatas terlihat nilai rata rata tingkat kepuasan yang didapat senilai 4.398

Tabel 12. Frequency Tangibles

\begin{tabular}{|l|r|r|r|}
\hline & $\begin{array}{c}\text { Website } \\
\text { terorganisasi } \\
\text { dengan baik }\end{array}$ & $\begin{array}{c}\text { Navigasi } \\
\text { terstandarisasi } \\
\text { secara konsisten }\end{array}$ & $\begin{array}{c}\text { Website } \\
\text { mudah } \\
\text { dimengerti }\end{array}$ \\
\hline Missing & 100 & 100 & 100 \\
Mean & 4.3400 & 0 & 0 \\
Median & 4.0000 & 4.1200 & 4.3400 \\
Minimum & 2.00 & 4.0000 & 4.0000 \\
Maximum & 5.00 & 3.00 & 2.00 \\
\hline
\end{tabular}

Berdasarkan tabel diatas terlihat nilai rata rata tingkat kepuasan yang didapat senilai 4.2667 
Tabel 13. Frequency Emphaty

\begin{tabular}{|r|r|r|r|r|}
\hline & $\begin{array}{c}\text { Tampilan } \\
\text { website } \\
\text { menarik dan } \\
\text { berisi } \\
\text { informasi } \\
\text { yang lengkap }\end{array}$ & $\begin{array}{c}\text { Website ini } \\
\text { menyediakan } \\
\text { informasi yang } \\
\text { akurat bagi } \\
\text { konsumen }\end{array}$ & $\begin{array}{c}\text { Informasi } \\
\text { yang tersedia } \\
\text { di website } \\
\text { jelas bagi } \\
\text { nasabah }\end{array}$ & $\begin{array}{c}\text { Komunikasi } \\
\text { dengan pihak } \\
\text { perusahaan } \\
\text { melalui } \\
\text { website }\end{array}$ \\
\hline Malid & 100 & 100 & 100 & 100 \\
Mean & 4.2900 & 0 & 0 & 0 \\
Median & 4.0000 & 4.0000 & 4.0000 & 3.6300 \\
Minimum & 3.00 & 3.00 & 2.00 & 4.0000 \\
Maximum & 5.00 & 5.00 & 5.00 & 1.00 \\
\hline
\end{tabular}

Berdasarkan tabel diatas terlihat nilai rata rata tingkat kepuasan yang didapat senilai 4.035 Tabel 14. Frequency Responsiveness

\begin{tabular}{|c|c|c|c|}
\hline & & $\begin{array}{c}\text { Masukkan dari } \\
\text { konsumen dilihat untuk } \\
\text { mengukur kepuasan } \\
\text { konsumen }\end{array}$ & $\begin{array}{l}\text { Permintaan direspon } \\
\text { dalam waktu } 24 \text { jam }\end{array}$ \\
\hline \multirow[t]{2}{*}{$\mathrm{N}$} & Valid & 100 & 100 \\
\hline & Missing & 0 & 0 \\
\hline \multicolumn{2}{|c|}{ Mean } & 4.7400 & 4.6800 \\
\hline \multicolumn{2}{|c|}{ Median } & 5.0000 & 5.0000 \\
\hline \multicolumn{2}{|c|}{ Minimum } & 4.00 & 4.00 \\
\hline \multicolumn{2}{|c|}{ Maximum } & 5.00 & 5.00 \\
\hline
\end{tabular}

Berdasarkan tabel diatas terlihat nilai rata rata tingkat kepuasan yang didapat senilai 4.71 
Tabel 15. Frequency Assurance

\begin{tabular}{|c|c|c|c|}
\hline & & $\begin{array}{l}\text { Terdapat jaminan } \\
\text { keamanan informasi pada } \\
\text { website }\end{array}$ & $\begin{array}{c}\text { Tersedia penggunaan } \\
\text { teknologi baru yang } \\
\text { menjamin keamanan } \\
\text { berkomunikasi melalui } \\
\text { website }\end{array}$ \\
\hline \multirow[t]{2}{*}{$\mathrm{N}$} & Valid & 100 & 100 \\
\hline & Missing & 0 & 0 \\
\hline \multicolumn{2}{|c|}{ Mean } & 4.3400 & 4.1200 \\
\hline \multicolumn{2}{|c|}{ Median } & 4.0000 & 4.0000 \\
\hline \multicolumn{2}{|c|}{ Minimum } & 2.00 & 3.00 \\
\hline \multicolumn{2}{|c|}{ Maximum } & 5.00 & 5.00 \\
\hline
\end{tabular}

Berdasarkan tabel diatas terlihat nilai rata rata tingkat kepuasan yang didapat senilai 4.23

Dari hasil pengamatan website secara langsung juga dapat dianalisa bahwa website tersebut masih berjalan 1 arah, isi website hanya berupa informasi. Untuk pelayanan secara online dan berinteraksi secara langsung masih belum bisa dilakukan. Walaupun demikian informasi yang didapat cukup lengkap, mulai dari pengenalan singkat mengenai perusahaan itu sendiri, visi dan misi, laporan keuangan, produk produk asuransi yang ditawarkan, berita terkini seputar perusahaan, serta PIC yang dapat dihubungi untuk masing-masing kotanya.

Namun dari hasil penelitian ini didapat bahwa pelayanan via website dianggap cukup membantu meningkatkan kepuasan nasabah khususnya untuk nasabah yang cukup mengenal teknologi gadget dan berada jauh dari posisi kantor ACPI. Kepopuleran nama perusahaan saat ini masih bertahap naik, tetapi jumlah nasabah dari awal berdiri sampai dengan saat ini cukup meningkat signifikan. Hal ini membuktikan bahwa ACPI cukup bisa diterima masyarakat dan mampu bersaing dengan para kompetitor.Walaupun masih perlu penyempurnaan dan pembaharuan terhadap isi web tersebut, dari hasil kuesioner didapatkan bahwa jawaban para responden dominan menyatakan bahwa pelayanan website PT. Asuransi Cakrawala Proteksi sudah "baik". Ini hendaknya dapat memberikan kepuasan lebih kepada nasabah sehingga bisa membantu mempromosikan PT. Asuransi Cakrawala Proteksi kepada masyarakat yang lebih luas. Dengan begitu maka nasabah PT. Asuransi Cakrawala Proteksi akan semakin bertambah dan tentunya bertahan dalam jangka waktu yang lamag.

\section{Kesimpulan}

Berdasarkan pembahasan tentang Analisis Kepuasan Pengguna Website Asuransi Untuk Peningkatan Pelayanan Asuransi (Studi Kasus www.cakrawalaproteksi.com), maka dapat diambil kesimpulan sebagai berikut (1) Website asuransi cukup berperan dalam memberikan kepuasan kepada nasabah; (2) Variabel responsiveness (ketanggapan) memiliki tingkat kepuasan paling tinggi kemudian divariabel assurance (jaminan) dan reliability (kehandalan), lalu variabel tangibles (bukti fisik) terakhir divariabel emphaty (empati); (3) Dengan adanya kepuasan nasabah tersebut, tentunya nasabah bisa membantu mempromosikan PT. Asuransi Cakrawala Proteksi kepada masyarakat yang lebih luas.

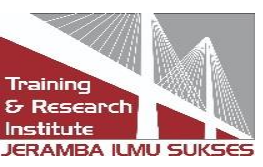


Dengan meningkatnya kepuasan nasabah tersebut, maka kualitas pelayanan asurasi juga harus ditingkatkan lebih baik lagi. Tampilan website sebaiknya diupdate secara berkala dan user interfacenya dibuat sebaik mungkin. Untuk pelayanan secara online ada baiknya segera diterapkan guna memaksimalkan fungsi website tersebut. Mengadakan sosialisasi lebih tentang adanya kemudahan berinteraksi dengan pihak asuransi via website untuk case case tertentu, selain itu juga bisa sebagai sumber informasi yang cukup efektif dan efisien untuk nasabah.

\section{Referensi}

Akbar, M., \& Antoni, D. (2019). E-supply chain management value concept for the palm oil industry. Jurnal Sistem Informasi, 15(2), 15-29.

Antoni, D., Akbar, M., \& Fatoni, F. (2018). Electronic government Rukun Tetangga model. Jurnal Sistem Informasi, 14(2), 64-73.

Ariana, S., Azim, C., \& Antoni, D. (2020). Clustering of ICT human resources capacity in the implementation of E-government in expansion area: A case study from Pali regency. Cogent Business \& Management, 7(1), 1754103.

Fauzi, F., Dencik, A. B., \& Asiati, D. I. (2019). Metodologi Penelitian Untuk Manajemen dan Akuntansi. Jakarta: Salemba Empat.

Parasuraman, A., Zeithaml, V.A., \& Berry, L.L. (1985). "A Conceptual Model of Service Quality and its Implication," Journal of Marketing, 49.

Parasuraman, A., Zeithaml, V.A., \& Berry, L.L. (1988). "SERVQUAL: a Multiple-item Scale for Measuring Customer Perceptions of Service Quality," Journal of Retailing, vol. 64, no. 1

\section{Copyrights}

Copyright for this article is retained by the author(s), with first publication rights granted to the journal.

This is an open-access article distributed under the terms and conditions of the Creative Commons Attribution license (http://creativecommons.org/licenses/by/4.0/) 